\title{
RECENT BIODIVERSITY IN ANAK KRAKATAU ISLAND
}

\author{
A.S. Rikha ${ }^{1}$, E. L. Widiastuti ${ }^{2}$, N. Nurcahyani², M. Kanedi² \\ ${ }^{1}$ Nature Conservation Agency of Lampung (BKSDA II), ${ }^{2}$ Biology Dept of University of Lampung \\ Email:1rikha_surya@yahoo.co.id, ${ }^{2}$ elwidi@yahoo.com
}

\begin{abstract}
Anak Krakatau Island is a volcanic island in the Krakatau preservation complex. With its regular explosions, ranging from2 80 times/day in the year 2013, it was expected that the biodiversity would experience many changes. In orderto determine the recent condition of the biodiversity, especially animal inhabitants, a survey was conducted within the island in June, 2013. The survey was made for mammal, bird, reptile, and invertebrate(ground, aerial, and arboreal) diversity. For mammals, 10 live traps were used along $100 \mathrm{~m}$ of line transect, birds and reptiles were adopted faced encountered method, while the invertebrate survey was conducted with visual techniques with a sweep net, pit-fall traps, and light traps. The result from the inventory (especially invertebrate) was followed by determining the diversity and dominance of species. Relative abundancewas also determined for mammals only. The survey indicated that there was 1 species of mammal with $20 \%$ of relativeabundance, 13 species of birds within 11 families, 2 species of reptiles, 58 species of insect, and 10 species of non-insect invertebrates, which consisted of 6 species of Araneae, 2 species of Scorpiones, 2 species of Chilopoda. The diversity indexfor insects was 4.011 with Bothriamyrmex sp. as subdominantin which its index of 2.86, and index for non-insects was 2.079. The result also was compared with the other 3 islands of the Krakatau complex and data collected in the last 10 years.
\end{abstract}

Key words: Anak Krakatau, volcanic, biodiversity

\section{INTRODUCTION}

Anak Krakatau Island emerged from the seawater around 1927,Since then, it has grown, reaching the height of more than $450 \mathrm{~m}$. It is the only volcanicislandamong four islands of the Krakatau preservation complex. The Anak Krakatau has shown regular eruptions, in this year (2013) its eruptionranging from 2-80 times/day, and much more eruptions in the last year, especially on $2^{\text {nd }}$ September, 2012, in which the eruption reacheda height of more than $500 \mathrm{~m}$. With its regular eruptions every year,it may be expected that the terrestrial biodiversity of the island would experience many changes.Many of the eruptions contained dust and particles. The total area of Anak Krakatau Island was 320 ha, and only $10 \%$ was occupied by living organisms. In order to determine the biodiversity of the Anak Krakatau Island, a survey was made on June 2013, especially for animal inhabitants.

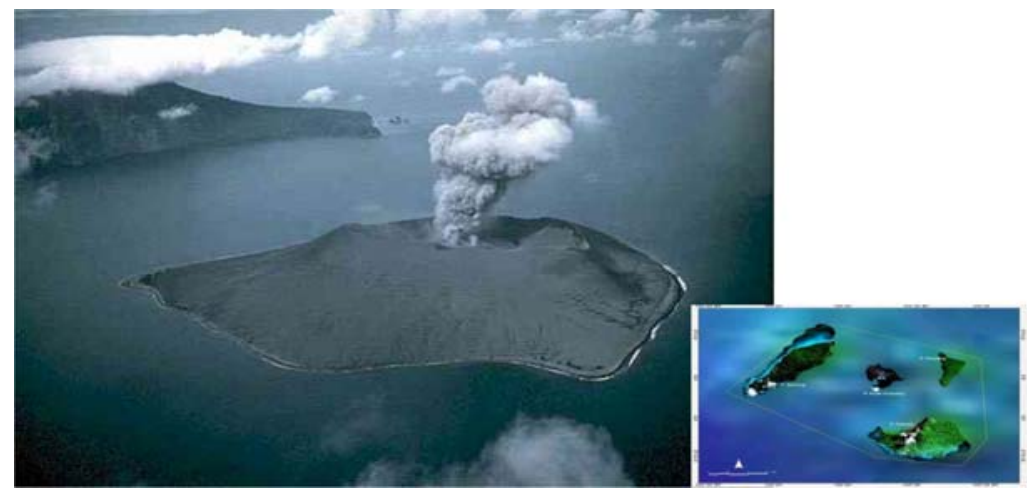

Figure 1. Anak Krakatau island in the complex of Krakatau islands.

ISSN 2413-0877 @ 2015 The Authors.

Published by KnowledgeE Publishing Services This is an open access article under the CC BY-NC-ND license (http://creativecommons.org/licenses/by-nc-nd/4.0)

Selection and Peer-review under responsibility of the 3rd ICBS-2013

Doi http://dx.doi.org/10.18502/kls.v2i1.151 


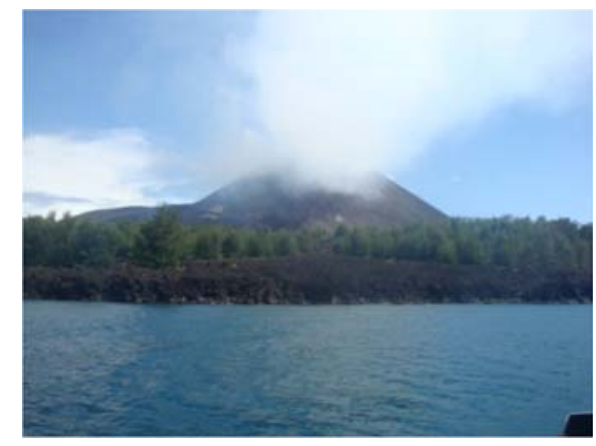

Figure 2. Anak Krakatau island

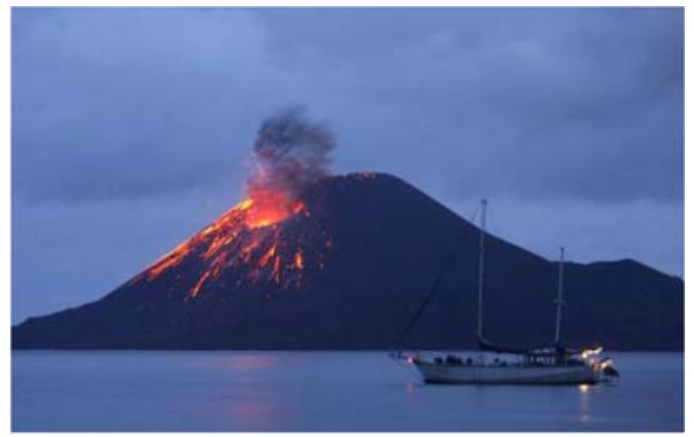

Figure 3. Anak Krakatau eruption September, 2012

\section{MATERIALS AND METHODS}

\section{A. Inventory made for small mammals}

The small mammal inventory was made only for terestrial mammals. Live traps (10) were placed along a100 $\mathrm{m}$ line transect. Each trap was baited with coconut and salty fish. The captured animals were identified by its characteristics and species before being released. It was followed by determining the diversity and dominance of species. Relative abundance was also determined but only for mammals, using modified Cox's (1996), such as,

$$
\begin{array}{lll}
\mathbf{R A}=[\mathbf{n i} / \mathbf{T}] \times \mathbf{1 0 0 \%} & \mathrm{RA} & : \text { Relative abundance } \\
\text { ni } & : \text { number of trapped individuals } \\
\mathrm{N} & : \text { number of traps }
\end{array}
$$

\section{B. Inventory made for birds (avian) and reptiles}

Face encountered method and visual techniques, as well as observation with binoculars was used for this inventory.

\section{Inventory made for Invertebrates}

The inventory was made intentionally for ground animals, included aerial and arboreal. The methods were used beside visual with face encountered method, trapping and netting were also employed. Visual face encountered was applied for invententoring birds, reptiles, and macro-invertebrates such as Papilionida, Orthoptera, Myriapoda, and Arachnida. Trappings were made for small/micro-invertebrates, such as by using asweep net,pit fall traps, and light traps. Trapped animals were preserved in $70 \%$ alcohol for further laboratory identification, which was conducted in the Zoological Lab of University of Lampung. Collected animalswere then determined for their diversity index of Shannon-Wiener, Sorensen index (similarity index), and domination index based on Cox's methods (1996).

Diversity index of Shannon-Wiener was based on:

$$
H^{\prime}=-\sum\left[\left(\frac{n_{i}}{N}\right) \times \ln \left(\frac{n_{i}}{N}\right)\right] \quad \begin{array}{ll}
\text { In which: } \\
\mathrm{ni} & : \text { individual number of species } \mathrm{i} \\
\mathrm{N} & : \text { total species in the area } \\
\mathrm{Ln} & \text { : natural log }
\end{array}
$$


Dominant index of Cox's (1996):

$$
D i=P i \times 100 \% \quad ; \quad P i=\frac{\mathrm{ni}}{\mathrm{N}} \quad \begin{array}{ll}
\mathrm{Di} & \text { : Dominant index of species } \mathrm{i} \\
\mathrm{Pi} & \text { : portion of species } \mathrm{i} \\
\mathrm{ni} & : \text { number of species } \mathrm{i} \\
\mathrm{N} & : \text { total number }
\end{array}
$$

Species dominant of the community in the area study then was grouped based on Jorgenssen's criteria, such as dominant $\left(D_{i}>5 \%\right)$, subdominant $\left(D_{i}=2 \%-5 \%\right)$, nondominant $\left(D_{i}<2 \%\right)$.

\section{RESULT AND DISCUSSION}

Mammals and birds found in the island can be seen in Table 1.

Table 1. Mammal and avian species found in Anak Krakatau Island

\begin{tabular}{clll}
\hline No & \multicolumn{1}{c}{ Species } & \multicolumn{1}{c}{ Families } & Total number \\
\hline 1 & Rattus tiomanicus & Muridae & 2 \\
2 & Treron capellei & Columbidae & \\
3 & Alcedoatthis & Alcedinidae & \\
4 & Pycnonotusaurigaster & Pycnonotidae & \\
5 & Priniafamiliaris & Silviidae \\
6 & Copsychussaularis & Turdidae \\
7 & Todirhamphussanctus & Alcedinidae \\
8 & Pycnonotusgoiavier & Pycnonotidae \\
9 & Haliasturindus & Accipitridae \\
10 & Artamus leucorhynchus & Artamidae \\
11 & Lonchurapunctulata & Ploceidae \\
12 & Otuslempiji & Strigidae \\
13 & Anthereptes simplex & Nectariniidae \\
14 & Apus affinis & Apodidae \\
\hline
\end{tabular}

Only one species of rat was found in Anak Krakatau, it was part of Muridae family - Ordo Rodentia. This species of rat was also identified by Thornton (1996). Comparedwith other islands (data was not shown), the relative abundance of the rat found in Anak Krakatau island was $20 \%$. The existing of this mammal was not away from any human activity, in this case in tourism, in which during the weekend, between 5-10 boats carried approximately 20 people per day to Anak Krakatau Island.

We found 13 species of bird in Anak Krakatau from 11 families. The number of birds differed slightly from a previous study conducted in April, 2012 (Martin, 2012) prior to the huge eruption of Anak Krakatau on September $2^{\text {nd }}, 2012$. It was expected that the migration of birds might take place on Anak Krakatau in that period.

Only two reptiles were found, Varanus salvator and Eretmochelys imbricata. This turtle was found laying its eggs on the beach of Anak Krakatau Island.

The total numberof insect species found in Anak Krakatau in this study was 58 from a 
total of 70 individuals and the Shannon-Wiener $\left(\mathrm{H}^{\prime}\right)$ index of 4.011(Table 2). Krakatau Island consisted of 4 different islands; comparedwith the other three different islands(data wasnot shown) species of Bothriamyrmex sp.in Anak Krakatauwas considered to be subdominant with its index of 2.86. The number of species found was different from early studies; 40 different species of butterfly was found in the year 1992 (New \& Thornton, 1992), and 30 species of beetles was also found in 2010 (Williams \& Miller, 2010). Presumably, regular eruptions of Anak Krakatau which mainly consisted of dust and hot particles affected the total species found in this year (2013).

\section{Arthropods non-insect found in Anak Krakatau Island}

From our survey/inventory of arthropods non-insect in Anak Krakatau Island we found 21 species. They consisted of 6 species of Araneae, 2 species of Scorpiones, and 2 species of Chilopods with the diversity index (Shannon-Wiener ( $\mathrm{H}^{\prime}$ ) Index) of 2.079 (Table 3). All of the total number of species that we found was significantly lower than the number species found by Zabka \& Nentwig (2000). They claimed that they found at least 33 species of Araneae. However, the species found for Scorpiones and Chilopods were not different compared with those reported by Thornton (1996).

Table 2. Insect diversity found in Anak Krakatau (2013)

\begin{tabular}{|c|c|c|}
\hline No & Taxon & Total species found \\
\hline & ORDO HYMNOPTERA & \\
\hline & Familia Formicidae (Semut) & \\
\hline 1 & Bothriamyrmex sp. & 2 \\
\hline 2 & Camponotus sp & 1 \\
\hline 3 & Dolichoderiis sp. & 1 \\
\hline 4 & Dorylus sp. & 1 \\
\hline 5 & Myrmica sp. & 1 \\
\hline 6 & Pheidole $s p$. & 2 \\
\hline 7 & Plagiolepis $s p$ & 1 \\
\hline 8 & Tetramorium sp & 1 \\
\hline \multirow[t]{2}{*}{9} & Tetraponera sp. & 1 \\
\hline & Familia Temitidae & \\
\hline \multirow[t]{2}{*}{10} & Nasutitermes $s p$ & 1 \\
\hline & Familia Apidae & \\
\hline 11 & Apis sp & 1 \\
\hline \multirow[t]{2}{*}{12} & Xylocopa sp & 2 \\
\hline & Familia Vespidae & \\
\hline \multirow[t]{2}{*}{13} & Polystes sp & 1 \\
\hline & Familia Sphecidae & \\
\hline \multirow[t]{2}{*}{14} & Bembix sp & 1 \\
\hline & Familia Megachilidae & \\
\hline \multirow[t]{2}{*}{15} & Megachile sp & 1 \\
\hline & Familia Halictidae & \\
\hline 16 & Halictus $s p$ & 1 \\
\hline 17 & Nomia sp & 1 \\
\hline
\end{tabular}




\begin{tabular}{|c|c|c|}
\hline No & Taxon & Total species found \\
\hline & ORDO COLLEOPTERA & \\
\hline & Familia Elateridae & \\
\hline \multirow[t]{2}{*}{18} & Alaus sp & 1 \\
\hline & Familia Curculionidae & \\
\hline \multirow[t]{2}{*}{19} & Schyphophorus sp & 1 \\
\hline & Familia Meloidae & \\
\hline \multirow[t]{2}{*}{20} & Mylabris sp & 1 \\
\hline & Familia Scarabaeidae & \\
\hline \multirow[t]{2}{*}{21} & Parastasia sp & 1 \\
\hline & Familia Lampyridae & \\
\hline \multirow[t]{3}{*}{22} & Pyrophanes sp & 1 \\
\hline & ORDO PAPILIONIDA & \\
\hline & Familia Papilionidae & \\
\hline 23 & Graphium agamemnon & 2 \\
\hline \multirow[t]{2}{*}{24} & Graphium sp & 1 \\
\hline & Familia Hesperiidae & \\
\hline 25 & Pelopidas sp & 1 \\
\hline \multirow[t]{2}{*}{26} & Potanthus sp & 1 \\
\hline & Familia Lycaenidae & \\
\hline 27 & Catochrysop sp & 1 \\
\hline 28 & Jamides sp & 1 \\
\hline \multirow[t]{2}{*}{29} & Zizula hylax & 1 \\
\hline & Familia Pieridae & \\
\hline 30 & Catopsilia pomona & 1 \\
\hline \multirow[t]{2}{*}{31} & Eurema sp & 2 \\
\hline & Familia Nymphalidae & \\
\hline 32 & Melanitis $s p$ & 1 \\
\hline 33 & Neptis sp & 1 \\
\hline 34 & Orsotriaena $s p$ & 1 \\
\hline \multirow[t]{2}{*}{35} & Tirumala sp & 1 \\
\hline & Familia Geometridae & \\
\hline 36 & Amata $s p$ & 1 \\
\hline \multirow[t]{2}{*}{37} & Astigysa sp & 2 \\
\hline & Familia Arctiidae & \\
\hline 38 & Euchromia sp & 1 \\
\hline \multirow[t]{2}{*}{39} & Spilosoma sp & 1 \\
\hline & Familia Noctuidae & \\
\hline 40 & Bastilla sp & 2 \\
\hline 41 & Phyllodes sp & 1 \\
\hline \multirow[t]{2}{*}{42} & Thyas sp & 1 \\
\hline & Familia Pyralidae & \\
\hline 43 & Acyperas sp & 2 \\
\hline \multirow[t]{2}{*}{44} & Epicrocis $s p$ & 1 \\
\hline & Familia Sphingidae & \\
\hline 45 & Clanis $s p$ & 2 \\
\hline
\end{tabular}




\begin{tabular}{|c|c|c|}
\hline No & Taxon & Total species found \\
\hline & ORDO ORTHOPTERA & \\
\hline & Familia Acrididae & \\
\hline 46 & Chorthippus sp & 2 \\
\hline \multirow[t]{2}{*}{47} & Oedipoda $s p$ & 1 \\
\hline & Familia Gryllidae & \\
\hline \multirow[t]{3}{*}{48} & Gryllacris sp & 1 \\
\hline & ORDO DIPTERA & \\
\hline & Familia Tephritidae & \\
\hline \multirow[t]{2}{*}{49} & Batrocera sp & 2 \\
\hline & Familia Dolichopodidae & \\
\hline \multirow[t]{3}{*}{50} & Agonosoma sp & 1 \\
\hline & ORDO HEMIPTERA & \\
\hline & Familia Fulgoridae & \\
\hline \multirow[t]{2}{*}{51} & Pyrops sp & 1 \\
\hline & Familia Reduviidae & \\
\hline \multirow[t]{2}{*}{52} & Melanolestes sp & 1 \\
\hline & Familia Coccidae & \\
\hline \multirow[t]{2}{*}{53} & Pulvinaria sp & 1 \\
\hline & Diaspididae & \\
\hline \multirow[t]{2}{*}{54} & Aspidiotus sp & 1 \\
\hline & Kerriidae & \\
\hline \multirow[t]{2}{*}{55} & Tachardina sp & 2 \\
\hline & Monophlebidae & \\
\hline \multirow[t]{2}{*}{56} & Icerya sp & 1 \\
\hline & Pseudococcidae & \\
\hline 57 & Planococcus sp & 1 \\
\hline 58 & Pseudococcus sp. & 1 \\
\hline \multicolumn{2}{|c|}{ Total individu } & 70 \\
\hline \multicolumn{2}{|c|}{ Total spesies } & 58 \\
\hline \multicolumn{2}{|c|}{ Shanon-Wiener $\left(\mathrm{H}^{\prime}\right)$ index } & 4.0108 \\
\hline
\end{tabular}

As well as the insect diversity, comparedwith the three different islands in the Krakatau preservation complex, the arthropod diversity of Anak Krakatau Island was similar (data of the three island of Krakatau Islands, namely Rakata Island, Panjuang Island, and Sertung Island was not shown), the number was 2.079 for Anak Krakatau, 2.079 for Rakata, 2.036 for Panjang, and 1.146 for Sertung. 
Table 3. Arthropod diversity found in Anak Krakatau (2013)

\begin{tabular}{|c|c|c|}
\hline No & Taxon & Total species found \\
\hline & CLASSIS ARACHNIDA & \\
\hline & ORDO ARANEAE & \\
\hline & Familia Lycosidae & \\
\hline 1 & Lycosa sp. & 1 \\
\hline \multirow[t]{2}{*}{2} & Pardosa sp. & 1 \\
\hline & Familia Salticidae & \\
\hline 3 & Artabrus sp & 1 \\
\hline 4 & Carrhotus sannio & 1 \\
\hline 5 & Marengo sp. & 1 \\
\hline \multirow[t]{3}{*}{6} & Myrmarachne sp. & 1 \\
\hline & ORDO SCORPIONES & \\
\hline & Familia Scorpionidae & \\
\hline 7 & Chelifer sp. & 1 \\
\hline \multirow[t]{3}{*}{8} & Thelyphonus caudatus & 1 \\
\hline & CLASSIS MYRIAPODA & \\
\hline & ORDO CHILOPODA & \\
\hline 9 & Scolopendra sp. & 1 \\
\hline 10 & Spirostreptus $s p$ & 1 \\
\hline \multicolumn{2}{|c|}{ Total } & 10 \\
\hline \multicolumn{2}{|c|}{ Number of Species } & 10 \\
\hline \multicolumn{2}{|c|}{ Shanon-Wiener $\left(\mathrm{H}^{\prime}\right)$ index } & 2.0794 \\
\hline
\end{tabular}

\section{CONCLUSION}

The animal diversity found in Anak Krakatau Island consisted of 13 species of birds (within 11 families), 2 species of reptiles, 58 species of insects, and 10 species of arthropod non-insect, which consisted of 6 species of Araneae, 2 species of Scorpiones, 2 species of Chilopoda. The diversity index for insects was 4.011 and Bothriamyrmex sp.was subdominantwith its index of 2.86, and index for non-insects was 2.079. The insect diversity of Anak Krakatau was higher compared with that of other arthropods, reptiles, avian (birds), and mammals. However this data needs further investigation.

\section{REFERENCES}

Cox, G. W. 1996. Laboratory manual of general ecology. 7th ed. Wm. C.Brown Company Publisher, Dubuque: $\mathrm{x}+278 \mathrm{hlm}$.

Martin, F. 2012. Keanekaragaman Jenis Burung di Pulau Anak Krakatau. Skripsi pada Fakultas Pertanian Universitas Lampung.

New, T.R., and I. Thornton. 1992. The Butterflies of Anak Krakatau, Indonesia: Faunal Development in Early Succession. Journal of the Lepidopterists'Society.46(2), 1992, 83-96.

Thornton, I.1996. Kakatau: The Distribution ang Reasemmbly of an Island Ecosystem. Harvard University Press. London, England.

Waite, S. 2000. Statistical ecology in practice: a guide to analysing environmental and ecological field data. Pearson Education Limited, Edinburgh Gate: xx + 414 hlm. 
Williams, D.J., and D.R. Miller. 2010. Scale insects (Hemiptera: Sternorrhyncha: Coccoidea) of the Krakatau Islands including species from adjacent Java. Zootaxa 2451: 43-52 (2010)

Zabka, M., and W. Nentwig. 2000. Salticidae (Arachnida: Araneae) of the Krakatau Islands (Indonesia). A Preliminary Approach. Ekológia (Bratislava) Vol. 19, Supplement 3, 293306, 2000. 